\title{
Analysis of AVOD Technology for Sharing on the Integrated Network Learning at Middle School
}

\author{
Zainul Abidin \\ Technology Education \\ Universitas Negeri Malang \\ zainul.abidin.fip@um.ac.id
}

\author{
Henry Praherdhiono \\ Technology Education \\ Universitas Negeri Malang \\ henry.praherdhiono.fip@um.ac.id
}

\author{
Yulias Prihatmoko \\ Technology Education \\ Universitas Negeri Malang \\ yulias.prihatmoko.fip@um.ac.id
}

\begin{abstract}
The research activity aims to strengthen students' cognitive and practical psychomotor in the domains of knowledge, attitudes and skills in Life-Based Learning through AVOD technology-rich media and the provision of extensive sharing features in integrated online learning. Cognitive and psychomotor practical is a manifestation of the implications of 21 st century abilities. The study provides evidence analysis for practical cognitive and psychomotor skills not directly compared to sharing in classrooms when face to face, but the focus only on sharing has been connected or connected. Cognitive and psychomotor practical is expected to be a learning material in class during face-to-face and online, so the most important key is to provide material sharing via Audio Video On Demand (AVOD) and the provision of special features that can accommodate sharing activities both synchronously and asynchronously.
\end{abstract}

Keywords—synchronous, asynchronous, learning-based life

\section{INTRODUCTION}

Practical cognitive and psychomotor skills are abilities that must be mastered by 21 st century students. It is important to remember that the analysis of evidence for thinking and activity skills is not directly compared to sharing in classrooms when face to face, but the focus only on sharing is connected or connected [1]. While Cognitive and Psychomotor Practical may also occur in the classroom during face-to-face [2],[3]. The most important key is to provide Audio Video on Demand (AVOD) sharing and provision of special features which can accommodate sharing activities both synchronously and asynchronously [4].

Research on e-learning applications that have been implemented at the State University of Malang (UM) by a team of Educational Technology Department researchers has been carried out since 2007. The development of INHERENT K-1 institutions has resulted in the On-line Learning Application System (SAPROL) which is used today. Researchers at the Education Technology Department stated that the problem of learning resources is the lack of teacher's writing, so that to make it easier to make an on-line editing container to facilitate the development of learning resources. The results of SAPROL's development and online learning resources have built a system that offers unique opportunities but still has limitations to building an independent learning environment for students. Praherdhiono stated that the convenience of ergonomics learning environments is supported by physical locations such as buildings in universities, libraries or classrooms, as well as learning devices both digital and non-digital devices [5]. This statement is sharpened in Trilling and Fadel that learning tools included in the learning environment are online learning tools, virtual schools, and combining digital and non-digital devices [6].

The opportunities offered by the learning environment of the State University of Malang Laboratory School are Learning Resources that can be accessed freely and openly for students of the State University of Malang Laboratory School. The learning resources are supplemented by user friendly application applications by empowering local networks and the Internet. Students can independently access but viewed from the learning design and application layout, the application still has limitations for use in mobile gadgets. This condition is not only applicable at Malang State University Laboratory School.

The ownership of the autonomy of learning by students needs to be supported by teacher control. Individual learning environments strengthen student autonomy in improving self-regulation learning [7],[8]. However, increasing responsibility and control on the part of students is not always the same for student motivation [9]. Students involved in network learning research must be more selfdirected. Not only did they navigate several applicationbased applications for the first time, they were also asked to play an active role in the learning process by making decisions about how to search, where to look, and why certain content fulfilled learning objectives. No longer smooth, map the path that defines what must be done to get "A". Traditional, lecture-based classes are designed as passive learning environments where the teacher communicates knowledge and learners respond [10]. Imagine the potential frustration that independent learning applies to students who are comfortable enough to be familiar with the direction of certain teachers with limited expectations.

The teacher as the manager of the pursuer must control the learner in a good and elegant way. University environmental teachers need to provide the right balance between learning control and student autonomy in order to facilitate independent learning activities in an independent learning environment [11],[12]. Learning activities with the control of student autonomy present challenges to teacher control in measuring, evaluating and evaluating learning outcomes. If students have primary control, then the teacher must consider how to measure, evaluate and evaluate [13]. The role of the teacher in a student-centered approach to learning is that of a facilitator and trainer [14]. 


\section{RESEARCH METHODS}

Learning design development methods based on the Model Davidson-Shivers and Rasmussen applications can be described as an activity that starts from the activities. The analysis process is carried out for high school students as the analysis is illustrated in the model and will only affect the design process and does not affect the simultaneous design.

The analysis process for UM Laboratory High School students and their development design is not a sequential process. But the analysis process has an influence on the design process of AVOD development. Processes that are in the Design environment are simultaneously affected indirectly. The analysis process includes two steps, namely teacher analysis and student analysis. Learning resources that use learning media in the form of mobile gadgets. The analysis material is as follows:

TABLE I

ANALYSIS METHOD

\begin{tabular}{|c|c|c|}
\hline $\begin{array}{c}\text { Analysis } \\
\text { Code }\end{array}$ & $\begin{array}{l}\text { Analysis } \\
\text { Material }\end{array}$ & Information \\
\hline SBX1 & $\begin{array}{l}\text { Learning } \\
\text { Resources }\end{array}$ & $\begin{array}{l}\text { - } \quad \text { What is the teacher using } \\
\text { - } \quad \text { Who makes teacher learning resources } \\
\text { - } \quad \text { When is the learning source used by } \\
\text { the teacher } \\
\text { - } \quad \text { Where the teacher uses } \\
\text { - Why do teachers use learning } \\
\text { - } \quad \text { resources } \\
\text { How do teachers use it }\end{array}$ \\
\hline SBX2 & & $\begin{array}{l}\text { - What students use } \\
\text { - } \quad \text { Who makes student learning resources } \\
\text { - } \quad \text { When to use learning resources used } \\
\text { by students } \\
\text { - Where students use } \\
\text { - } \quad \text { Why students use learning resources } \\
\text { - How students use it }\end{array}$ \\
\hline MPX1 & & $\begin{array}{l}\text { - What is the teacher using } \\
\text { - Who makes teacher learning media } \\
\text { - } \quad \text { When is the learning media used by } \\
\text { the teacher } \\
\text { - Where teachers use learning media } \\
\text { - } \quad \text { Hhy do teachers use learning media }\end{array}$ \\
\hline MPX2 & & $\begin{array}{l}\text { - What students use } \\
\text { - Who makes student learning media } \\
\text { - } \quad \text { When is the learning media used by } \\
\text { students } \\
\text { - Where students use learning media } \\
\text { - } \quad \text { Why students use learning media } \\
\text { How students use learning media }\end{array}$ \\
\hline
\end{tabular}

\section{RESULT AND DiscUSSION}

Research has conducted analysis and development of learning models. The process of analysis is done to high school students as described by the analyst is the user and the media to produce a model and will have an impact on the design process only and does not affect the simultaneous design.

The analysis process for UM Laboratory High School students and their development design is not a sequential process. But the analysis process has an influence on the design process of AVOD development. Processes that are in the design environment are simultaneously affected indirectly. The analysis process includes two steps, namely teacher analysis and student analysis. Learning resources that use learning media in the form of mobile gadget. The analysis material is as follows:

\section{1) Analysis results learning resources in $S B X 1$ and $S B X 2$ codes are teachers and students in general using android on the selection of smart phones.}

Teachers generally have gadget like students. The learning resources used are generally obtained from reference books agreed upon by the principal and other teachers. Learning resources do not actually have to be from a book, but are still rarely used. Teachers and students obtain learning resources in the understanding stage from the internet. Learning activities at school and work assignments are the most learning resources from the teacher and agreed upon are used.

The teacher uses learning resources when conducting teaching activities. For learning design activities, the teacher generally uses the guidelines for the development of RPP and Syllabus. There are no learning resources except those that have been determined by the government or school agreements that are used to design learning. Teachers are generally very pragmatic. The use of learning resources is intended to facilitate learning by considering how to use existing learning resources and not need to bother to develop them

Analysis on SBX2 also doesn't differ much in general. Even students also use students to use learning resources as well as from school agreements. It is rare for students to use the internet to develop themselves. Every now and then look for definitions from the google search engine and be used to do assignments given by the teacher.

2) MPX1 and MPX2 results in general are very limited use of learning media. In general, teachers and students only dichotomize traditional and modern learning media according to teacher and student knowledge.

Teachers generally use whiteboards and presentation media. The needs needed by the teacher are presentations and students listen more. Inquiry, interactive and modified media are hardly used. Media only serves to expose content. Learning media is generally developed by teachers.

Even the teachers never gathered to discuss, analyze and evaluate the learning media. Teachers are only the object of learning media training, not yet able to be the subject of learning media. At MPX2 students may be more advanced by digging from various sources such as search engines and have used WhatsApp to discuss assignments. Learning media has not been actively used in learning.

\section{3) The desire of students and teachers is the emergence of media that can bridge learning desires.}

Teachers are generally very busy with learning administration which must be reported as a requirement of professionalism. A strong desire and intention is always there for the teacher to carry out the task as a teacher and educator, but it is felt very difficult because the change in the learning culture that enters the work becomes a demand for professionalism. Junior teachers with graduation after 
the establishment of professional allowances for teachers generally understand the consequences of work as teachers and professional educators. But for senior teachers, developing learning is a burden.

\section{CONCLUSION}

The analysis shows the potential for practical cognitive and psychomotor strengthening of students in the domains of knowledge, attitudes and skills in Life-Based Learning through AVOD technology-rich media and the provision of extensive sharing features in integrated online learning. Specific development of very rich media includes: Developing learning resources with Audio and Visual on Demand (AVOD) technology organized by QR codes. The learning source has been organized and encoded using a $\mathrm{QR}$ code and will easily find its storage location and be easily heard and viewed through the mobile gadget.

Organizing learning resources was developed for learning needs to provide support for students' autonomy in the search and supply of their relevant materials, consultation in all types of problem solving and finding solutions, lectures based on the chosen theme in sharing plenary with students and in accordance with the curriculum. Develop learner design that provides full learning autonomy to students and control procedures in the form of measurement, assessment and evaluation of learners for teachers through learning in the network.

The study has important and strategic value in order build to introduce a learning model that coordinates the audio and visual learning resources through the delay that is placed in the on-line storage learning network for students to meet learning needs in independent learning environment through mobile gadgets. Learning-centered education is an elegant approach to learning through balancing. Teacher's control by measuring, evaluating and evaluating learning activities that do not clash with the increase in student autonomy. The students will later easily control the learning source is basically, network learners in training. Therefore, the level of structure is needed for the scaffolding of the learning process.

Students use synchronous communication, Really Simple Syndication (RSS), information management, and human contact for learning. Examples of application applications that appear for each of these categories are highlighted. The Model Student Network establishes a basis that begins to address what level of structure is needed to facilitate network learning while providing a foundation for greater learner control over personal learning environments.

\section{REFERENCES}

[1] Davidson-Shivers, G., Tanner, E., Muilenburg, L., 2000. Online Discussion: How Do Students Participate?

[2] Kenyhercz, F., Nagy, B., 2017. Examination of psychomotor development in relation to social-environmental factors in preterm children at 2 years old. Orv. Hetil. 158, 31-38.

[3] Vandenbroucke, L., Spilts, J., Verschueren, K., Piccinin, C., Baeyens, D., 2017. The Classroom as a Developmental Context for Cognitive Development: A Meta-Analysis on the Importance of Teacher Student Interactions for Children's Executive Functions. Rev. Educ. Res. 0034654317743200.

[4] Smith *, PJ, 2005. Learning preferences and readiness for online learning. Educ. Psychol. 25, 3-12.

[5] Praherdhiono, H., 2016. Standard Ergonomics Based Learning Environment Comfort Measurement Program. Dissertation and Postgraduate Program Thesis. UM.

[6] Trilling, B., Fadel, C., 2009. 21st century skills: Learning for life in our times. John Wiley \& Sons.

[7] Beckers, J., Dolmans, D., Van Merriënboer, J., 2016. e-Portfolios enhances students' self-directed learning: A systematic review of influencing factors. Australas. J. Educ. Technol. 32, 2.

[8] Broadbent, J., Poon, WL, 2015. Self-regulated learning strategies \& academic achievements in online higher education learning environments: A systematic review. Internet High. Educ. 27, 1-13.

[9] Reeves, TC, 2006. Design research from a technology perspective. Educ. Dec. Res. 1, 52-66.

[10] Chen, R.-J., 2010. Investigating models for preservice teachers' use of technology to support student-centered learning. Comput. Educ. 55, $32-42$.

[11] Beaudoin, M., 1990. The instructor's changing role in distance education. Am. J. Distance Educ. 4, 21-29.

[12] McLoughlin, C., Lee, MJ, 2010. Personalized and self regulated learning in the application 2.0 era: International experiments of innovative pedagogy using social software. Australas. J. Educ. Technol. 26.

[13] Pedersen, S., Liu, M., 2003. Teachers' beliefs about issues in the implementation of a student-centered learning environment. Educ. Technol. Res. Dev. 51, 57.

[14] Wang, Y., Guo, Y., Chen, Y., 2016. Accurate and early prediction of users lives in online video-on-demand systems, in: Signal Processing (ICSP), 2016 IEEE 13th International Conference On. IEEE, pp. 969974. 